\title{
Penggunaan Media Interaktif Berbasis Adobe Flash Untuk Meningkatkan Hasil Pembelajaran Teknologi Jaringan Luas Materi Nirkabel
}

\author{
Nizar Agus $\mathrm{D}^{1^{*}}$ iD \\ 1,2,3 SMK Negeri I Dlanggu Mojokerto, Mojokerto, Indonesia \\ *Corresponding author: nizaragus4d@gmail.com
}

\begin{abstract}
Tujuan penelitian ini adalah untuk menjelaskan penggunaan media pembelajaran interaktif berbasis adobe flash dapat meningkatkan hasil belajar teknologi jaringan luas materi Nirkabel" Siswa Kelas XI TKJ. Penelitian ini menggunakan penelitian tindakan kelas yang dilakukan dengan 2 siklus. Yang dijadikan subjek dalam penelitian tindakan kelas ini adalah siswa kelas XI TKJ, dengan jumlah siswa 32 orang yang terdiri dari 18 orang laki-laki dan 14 orang perempuan. Instrumen penelitian yang digunakan sebagai alat pengumpulan data, yaitu: instrumen tes, yang terdiri atas: (a) Media Pembelajaran interaktif Berbasis adobe flash dan (b) tes hasil belajar siswa. setelah adat terkumpul data kemudian dianalisis dengan menggunakan statistik deskriptif. Berdasarkan hasil penelitian menunjukkan bahwa media pembelajaran interaktif dengan peranti lunak adobe flash pada mata pelajaran jaringan dasar telah berhasil diuji keefektifan, ke menarikan, dan efisiensinya dalam pembelajaran. Hal tersebut sudah menunjukkan bahwa media pembelajaran interaktif yang dikembangkan cukup mampu memenuhi kebutuhan guru sebagai alternatif strategi dan mampu meningkatkan strategi guru dalam menyampaikan isi pesan yang terkandung dalam pembelajaran, serta mampu memenuhi kebutuhan akan kejenuhan siswa/pebelajar dalam pembelajaran di dalam kelas X TKJ.
\end{abstract}

Keywords: Media interaktif, Adobe flash, Nirkabel

\section{Abstract}

This study aims to explain the use of interactive learning media based on adobe flash to improve learning outcomes of wireless material network technology of Grade XI TKJ Students. This study uses a classroom action research conducted in 2 cycles. The subjects in this classroom action research were students of Grade XI TKJ, with 32 students consisting of 18 boys and 14 girls. The research instrument used as a data collection tool, namely: a test instrument, which consists of: (a) Adobe Flash-based interactive learning media and (b) student learning outcomes tests. After the custom is collected the data is then analyzed using descriptive statistics. Based on the results of the study, it shows that interactive learning media with adobe flash software on basic network subjects have been successfully tested for their effectiveness, attractiveness, and efficiency in learning. This has shown that the interactive learning media developed are sufficient to meet the needs of teachers as an alternative strategy and be able to improve teacher strategies in conveying the message content contained in learning, as well as being able to meet the needs of student / learner saturation in learning in Grade XI TKJ

Keywords: Interactive media, Adobe Flash, Wireless

$\begin{array}{ll}\text { History: } & \text { Publisher: Undiksha Press } \\ \text { Received : 4 Juni } 2020 & \text { Licensed: This work is licensed under } \\ \text { Revised : 1 Juli } 2020 & \text { a Creative Commons Attribution 3.0 License } \\ \text { Accepted : 20 Juli } 2020 & \text { Published : 30 Juli } 2020\end{array}$




\section{Introduction}

Sekolah Menengah Kejuruan (SMK) sebagai bagian dari sistem pendidikan nasional merupakan pendidikan pada jenjang menengah yang menyiapkan peserta didiknya untuk memasuki dunia kerja dengan berbagai ilmu pengetahuan dan keahlian sehingga diharapkan mampu mengembangkan ilmu dan keahlian yang diperolehnya itu demi kemajuan dirinya, masyarakat dan bangsa. Ditegaskan dalam UU Sisdiknas No. 20 Tahun 2003 Pasal 15 yang menyatakan bahwa SMK sebagai bentuk satuan pendidikan kejuruan merupakan pendidikan menengah yang mempersiapkan peserta didik terutama untuk bekerja dalam bidang tertentu (Syahroni, 2014). Dalam suatu proses pembelajaran setidaknya terdapat dua aspek yang dapat mempengaruhi hasil pembelajaran yaitu metode pembelajaran dan media pembelajaran. Kedua aspek ini tentunya saling berkaitan, pemilihan salah satu metode pembelajaran tentunya akan berdampak pada jenis media pembelajaran yang dibutuhkan. Tidak menutup kemungkinan bahwa pemilihan suatu media pembelajaran juga harus memperhatikan tujuan pembelajaran, jenis mata pelajaran dan karakter siswa. Media pembelajaran dibuat sesuai dengan tujuan dari sebuah mata pelajaran.

Mata pelajaran yang cenderung bersifat teoritis atau hafalan dalam proses belajarnya mungkin cukup menggunakan buku panduan atau modul saja. Hal ini tentu berbeda bila kita belajar praktik atau sesuatu yang harus diaplikasikan yang membutuhkan banyak informasi. Di dalam pelajaran praktik dalam memvisualisasikan suatu langkah kerja terkadang mengalami kesulitan yang disebabkan oleh peralatan, bahan, biaya, dan keterbatasan dari pengajar itu sendiri. Kegiatan pembelajaran di SMK pada umumnya dilaksanakan dengan cara team teaching pada kelas besar yang diampu oleh lebih dari seorang guru. Kondisi kelas yang besar terkadang membuat siswa kurang bisa untuk fokus terhadap materi yang diajarkan. Hal ini ditambah lagi dengan cara penyampaian materi yang terkadang berbeda antara guru satu dengan yang lainnya. Hal tersebut menyebabkan siswa menjadi bingung dengan materi yang disampaikan. Hasil observasi lapangan (kelas) pada kegiatan proses belajar mengajar (PBM) pada umumnya dan di SMK Negeri 1 Dlanggu pada khususnya menunjukkan aktivitas siswa dalam proses belajar-mengajar rendah dan bersifat pasif yaitu cenderung hanya sebagai penerima saja. Siswa kelihatan tidak bersemangat banyak yang mengantuk terutama pada jam-jam setelah istirahat mulai jam 11.00 WIB dan kurang memperhatikan materi yang disampaikan guru. Siswa kurang berminat selama mengikuti proses pembelajaran, siswa kurang berani mengemukakan pendapatnya bila diberi pertanyaan oleh guru sehingga proses kegiatan belajar mengajar didominasi dengan kegiatan mencatat di papan tulis dan ceramah.

Minat belajar siswa penting untuk ditingkatkan karena mempermudah proses belajar serta untuk mencapai prestasi yang lebih tinggi dari sebelumnya. Minat merupakan alat motivasi yang pokok karena proses belajar akan berjalan lancar kalau disertai minat (Oktiani, 2017). Mengenai minat ini antara lain dapat dibangkitkan dengan cara-cara sebagai berikut: menggunakan berbagai macam metode mengajar, membangkitkan adanya suatu kebutuhan, memberi kesempatan untuk mendapatkan hasil yang lebih baik (Syaparuddin \& Elihami, 2020). Seiring dengan itu, untuk meningkatkan minat belajar siswa maka peranan perkembangan teknologi sangatlah penting terutama dalam bentuk sajian multimedia dalam bentuk audio visual yang menyajikan bentuk visualisasi lebih menarik. Anih, (2016) menyatakan bahwa berbagai inovasi pendidikan terus dilakukan seiring dengan perkembangan teknologi terutama ICT (Information Computer Technology). ICT dalam hal ini komputer dengan dukungan multimedia dapat menyajikan sebuah tampilan berupa teks non sekuensial, non linear, dan multidimensional dengan percabangan tautan dan simpul secara interaktif. Tampilan tersebut akan membuat pengguna (user) lebih leluasa memilih, menyintesis, dan mengelaborasi pengetahuan yang ingin dipahaminya. Walhasil komputer dapat mengakomodasi siswa yang lamban menerima pelajaran, karena komputer tidak pernah 
bosan, sangat sabar dalam menjalankan instruksi, seperti yang diinginkan. Salah satu manfaat penggunaan metode pembelajaran dengan teknologi adalah agar siswa dapat mencari sendiri dan langsung mengalami proses belajar. Sehingga mengembangkan pemahaman dan berpikir kritis serta menghindari terjadinya pembelajaran konvensional yang terus-menerus. Penyampaian materi ajar yang tidak bervariasi dapat menjadi penyebab tidak tercapainya tujuan pembelajaran yang diinginkan. Dengan adanya variasi dalam pembelajaran diharapkan siswa dapat belajar secara mandiri yang pada akhirnya akan mengembangkan seluruh kemampuan aspek pribadi masing-masing siswa.

Media pembelajaran interaktif merupakan salah satu solusi yang diharapkan akan memotivasi siswa untuk belajar mandiri, kreatif, efektif dan efisien, (Akbar et al., 2015; Nursidik \& Suri, 2018). Selain itu dengan Media Pembelajaran Interaktif ini, diharapkan dapat mengurangi kejenuhan siswa karena selama ini proses pembelajaran yang dilakukan oleh kebanyakan sekolah adalah metode tatap muka (ceramah). Banyak penelitian yang dilakukan yang berkaitan tentang media pembelajaran interaktif, antara lain Windiartha, (2017) menyatakan bahwa produk berupa media pembelajaran interaktif berbasis adobe flash player efektif diterapkan dalam proses pembelajaran. Penelitian Hidayah et al. (2017) menyatakan bahwa penerapan media pembelajaran interaktif berbasis adobe flash player meningkatkan minat dan motivasi siswa. Farida Hasan Rahmaibu (2017) menyatakan bahwa media pembelajaran interaktif berbasis adobe flash player efektif dan layak di terapakan pada pembelajaran PPKn. (Usfiyana, 2019) media pembelajaran interaktif berbasis Adobe Flash CS6 standar kompetensi memahami dasar-dasar penggunaan internet/intranet dan menggunakan internet untuk memperoleh informasi dianggap layak dijadikan sebagai media pembelajaran. Sukartiningsih (2018) menyatakan bahwa penggunaan media pembelajaran interaktif berbasis adobe flash valid, praktis, dan efektif untuk diterapkan dalam pembelajaran menulis teks eksposisi siswa kelas III sekolah dasar.

Oleh karena itu, untuk menanggapi permasalahan yang terdapat pada latar belakang tersebut diatas, Penggunaan media pembelajaran interaktif siswa kelas XI Teknik Komputer dan Jaringan (TKJ) 2 di SMK Negeri 1 Dlanggu Kabupaten Mojokerto pada Mata Pelajaran Teknologi jaringan berbasis luas dengan menggunakan media pembelajaran interaktif yang yang berbasis Adobe Flash yang berisikan rangkuman materi dengan harapan untuk menarik minat belajar siswa sehingga hasil belajarnya lebih baik lagi

\section{Materials and Methods}

Kegiatan yang dilakukan oleh peneliti pada tahap perencanaan adalah: 1) Peneliti melakukan analisis kurikulum untuk menentukan standar kompetensi dan kompetensi dasar yang disampaikan kepada siswa dengan menggunakan media pembelajaran interaktif berbasis adobe flash, 2) Membuat RPP siklus I dengan media pembelajaran interaktif berbasis adobe flash, 3) Membuat lembar observasi siklus I untuk melihat bagaimana kondisi belajar mengajar di kelas ketika latihan dan kerja kelompok dilaksanakan, 4) Membuat Lembar Kerja Siswa siklus I, 5) Membentuk kelompok yang bersifat heterogen baik dari segi kemampuan akademis, jenis pembelajaran dengan menggunakan media pembelajaran interaktif berbasis adobe flash pada siklus I, 6) Menyusun alat evaluasi pembelajaran berdasarkan perkembangan untuk dilaksanakan pada siklus II serta menyiapkan instrumen pendukung pembelajaran lainnya.

Pertama, Selama pembelajaran langsung dilakukan observasi untuk mengetahui prosedur pelaksanaan pembelajaran interaktif berbasis adobe flash. dalam meningkatkan hasil belajar pada proses pembelajaran produk kreatif dan kewirausahaan. Langkah selanjutnya bagi peneliti adalah pelaksanaan. Pada tahap ini perencanaan yang sudah dibuat peneliti akan dilaksanakan dalam kegiatan pembelajaran. Tahap pengamatan atau observasi dilakukan bersamaan dengan pelaksanaan tindakan. Pada tahap ini peneliti di bantu oleh guru 
atau teman sejawat untuk mencatat semua hal yang diperlukan dalam penelitian berupa pengumpulan data. Ketika dilaksanakan kegiatan pembelajaran kebanyakan siswa yang tidak tahu dan tidak paham, sehingga tidak bisa menjawab pertanyaan yang berkenaan dengan soal-soal yang berhubungan dengan nirkabel. Karena ketidak pahaman dan ketidakmampuan dalam menjawab soal-soal yang berhubungan dengan nirkabel, suasana kelas tampak gaduh dan sulit dikendalikan.

Kedua, Tahap yang terakhir merupakan kegiatan untuk mengemukakan kembali apa yang sudah dilakukan. Istilah refleksi berasal dari kata bahasa Inggris reflection yang diterjemahkan dalam bahasa Indonesia. Pada tahap ini peneliti menyimpulkan data atau hasil yang diperoleh selama proses penelitian itu berlangsung. Selain itu juga dimaksudkan sebagai upaya untuk memahami proses, masalah, persoalan, dan kendala nyata dalam proses tindakan. Dalam hal ini peneliti melakukan penilaian sebagai tugas akhir dari siklus.

Latar penelitian adalah tempat yang digunakan dalam melakukan penelitian untuk memperoleh data yang diinginkan. Dalam Penelitian ini, latar penelitiannya adalah di SMKN 1 Dlanggu Mojokerto. Penelitian tindakan kelas ini dilaksanakan secara di SMKN 1 Dlanggu Mojokerto. Yang dijadikan subjek dalam penelitian tindakan kelas ini adalah siswa kelas XI TKJ 2, dengan jumlah siswa 32 orang yang terdiri dari 18 orang laki-laki dan 14 orang perempuan. Sebelum penelitian tindakan kelas ini dilakukan, peneliti melakukan persiapan berupa kegiatan-kegiatan sebagai berikut: a) Studi awal tentang pelaksanaan peningkatan keaktifan siswa dalam pembelajaran nirkabel siswa kelas XI TKJ2; b) Mengidentifikasi permasalahan dalam pelaksanaan peningkatan keaktifan siswa dalam pembelajaran nirkabel siswa kelas XI TKJ 2; c) Merencanakan rencana penelitian, pada tahap ini peneliti menyusun serangkaian kegiatan secara menyeluruh berupa siklus-siklus tindakan kelas meliputi peningkatan keaktifan siswa dalam pembelajaran nirkabel dan meliputi peningkatan keaktifan siklus I dan II; d) Menyusun instrumen sebagai pedoman observasi terhadap pelaksanaan keaktifan siswa kelas XI TKJ 2 mengikuti pembelajaran nirkabel dalam penelitian tindakan kelas; e) Penyusunan indikator keberhasilan model pembelajaran dengan menggunakan media interaktif berbasis adobe flash yang berupa keaktifan siswa kelas XI TKJ 2 dalam setiap pembelajaran nirkabel.

Dalam penelitian ini digunakan satu jenis instrumen penelitian sebagai alat pengumpulan data, yaitu: instrumen tes, yang terdiri atas: (a) Media Pembelajaran interaktif Berbasis adobe flash. Dalam penelitian ini, instrumen digunakan untuk menentukan tipe model pembelajaran yang sesuai dalam proses belajar mengajar. Instrumen berbentuk tes objektif pilihan ganda dengan dua alternatif jawaban sebanyak 20 butir soal. dan (b) tes hasil. Instrumen Hasil Belajar Siswa. Instrumen tes digunakan untuk mengukur variabel hasil belajar siswa. Instrumen tes ini berbentuk tes objektif pilihan ganda dengan 5 (lima) alternatif jawaban sebanyak 20 butir soal. Instrumen tes ini dikembangkan sendiri oleh peneliti. Instrumen tes dalam penelitian ini dibedakan menjadi dua, yaitu: instrumen pre-test dan posttest. Tujuannya untuk mengetahui kemampuan yang telah siswa miliki sebelum dan setelah mendapatkan perlakuan. Soal post-test dibuat sama dengan soal pre-test, tetapi dengan urutan nomor butir soal yang diubah.

\section{Results and Discussion Paparan Hasil Observasi Pra-siklus}

Data hasil pretes kelompok siswa sebelum mendapat Pembelajaran interaktif berbasis adobe flash, dianalisis dengan untuk mengetahui tingkat pengetahuan dan pemahaman tentang materi belajar yang berhubungan dengan nirkabel. 
Tabel 1. Hasil Belajar Siswa Pra Siklus

\begin{tabular}{cccc}
\hline No. & & Materi Ajar & Rata-rata Nilai \\
\hline 1 & Jaringan luas & & 69,00 \\
\hline 2 & Nirkabel & & 69,85 \\
\hline & & Rata-Rata Nilai & $\mathbf{6 9 , 4 2 5}$ \\
\hline
\end{tabular}

Berdasarkan isi Tabel 1 terlihat bahwa nilai pretes kelompok siswa sebelum mendapat perlakuan pembelajaran dengan media Interactife berbasis adobe flash adalah 69,425.

\section{Paparan Hasil Tindakan Siklus 1}

Pertama, perencanaan di mulai dengan membentuk kelompok diskusi. Siswa yang berjumlah 32 siswa dibagi menjadi 5 kelompok sehingga masing-masing kelompok berjumlah 7 siswa. Materi pelajaran yang diajarkan pada siklus I ini adalah pokok bahasan nirkabel. Proses pembelajaran ini menggunakan pendekatan permainan yang diterapkan oleh guru secara langsung dalam pembelajaran di lapangan. Kegiatan yang dilakukan oleh peneliti pada tahap perencanaan adalah: a) Peneliti melakukan analisis kurikulum untuk menentukan standar kompetensi dan kompetensi dasar yang disampaikan kepada siswa dengan menggunakan pembelajaran interaktif berbasis adobe flash Membuat RPP siklus I dengan model pembelajaran interaktif berbasis adobe flash, b) Membuat lembar observasi siklus I untuk melihat bagaimana kondisi belajar mengajar dikelas ketika latihan dan kerja kelompok dilaksanakan, c) Membuat Lembar Kerja Siswa siklus I, d) Membentuk kelompok (terdiri dari 5 siswa) yang bersifat heterogen baik dari segi kemampuan akademis, jenis pembelajaran interaktif berbasis adobe flash pada siklus I, e) Menyusun alat evaluasi pembelajaran berdasarkan perkembangan pada siklus II serta menyiapkan instrumen pendukung pembelajaran lainnya.

Kedua, Pelaksanaan kegiatan belajar mengajar pembelajaran interaktif berbasis adobe flash untuk siklus I dengan jumlah siswa 32 siswa. Dalam hal ini Peneliti bertindak sebagai guru. Pengamatan (observasi) dilaksanakan bersamaan dengan pelaksanaan pembelajaran. Pelaksanaan tindakan siklus I dapat diuraikan sebagai berikut: a) Guru mengawali pembelajaran dengan mengucapkan salam dan menanyakan jumlah siswa yang hadir, b) Guru melaksanakan apersepsi, c) Guru membagi siswa dalam kelompok diskusi, kemudian memberi tugas yang berkaitan dengan penggunaan pembelajaran interaktif berbasis adobe flash, d) Guru memberi tugas kepada siswa untuk mempresentasikan di depan kelas hal-hal yang berkaitan dengan nirkabel dengan menggunakan pembelajaran interaktif berbasis adobe flash, waktu untuk presentasi adalah 10 menit untuk masing-masing individu, e) Guru menindaklanjuti pembelajaran itu dengan menerangkan materi pelajaran tentang hal-hal yang berkaitan dengan nirkabel menggunakan pembelajaran interaktif berbasis adobe flash, waktu yang digunakan selama 10 menit, f) Guru bersama-sama siswa mendemonstrasikan penggunaan pembelajaran pendekatan permaianan materi nirkabel . selama 10 menit, g) Guru bersama-sama siswa melukukan kegiatan Praktek dengan materi nirkabel, h) Guru memberikan tugas secara individu selama 15 menit, i) Guru menutup pelajaran dengan mengucapkan salam.

Dalam siklus pertama ini, berdasarkan catatan peneliti, siswa masih kurang dapat bekerja sama, kerja kelompok masih kurang dapat berjalan sebagaimana yang diharapkan, presentasi belum banyak mendapat perhatian/tanggapan dari pendengar (siswa dari kelompok lain).

Selama pembelajaran berlangsung dilakukan observasi untuk mengetahui pengaruh kegiatan pembelajaran dalam meningkatkan hasil belajar siswa dalam pembelajaran interaktif berbasis adobe flash materi nirkabel. Pada pembelajaran ini siswa yang masuk sebanyak 32 siswa. Guru mengamati, ternyata pada setiap kelompok masih didapati siswa yang kurang memperhatikan pelajaran yang berkaitan dengan nirkabel dan masih berbicara dengan teman 
didekatnya tentang hal-hal yang tidak berkaitan dengan materi pembelajaran. Melalui serangkaian pertanyaan yang disampaikan kepada siswa, sebagian diantaranya belum memahami dan bahkan tidak tau apa yang di diskusikan dalam kelompoknya. Adapun hasil belajar siswa setelah kegiatan yang diberikan dalam Siklus I.

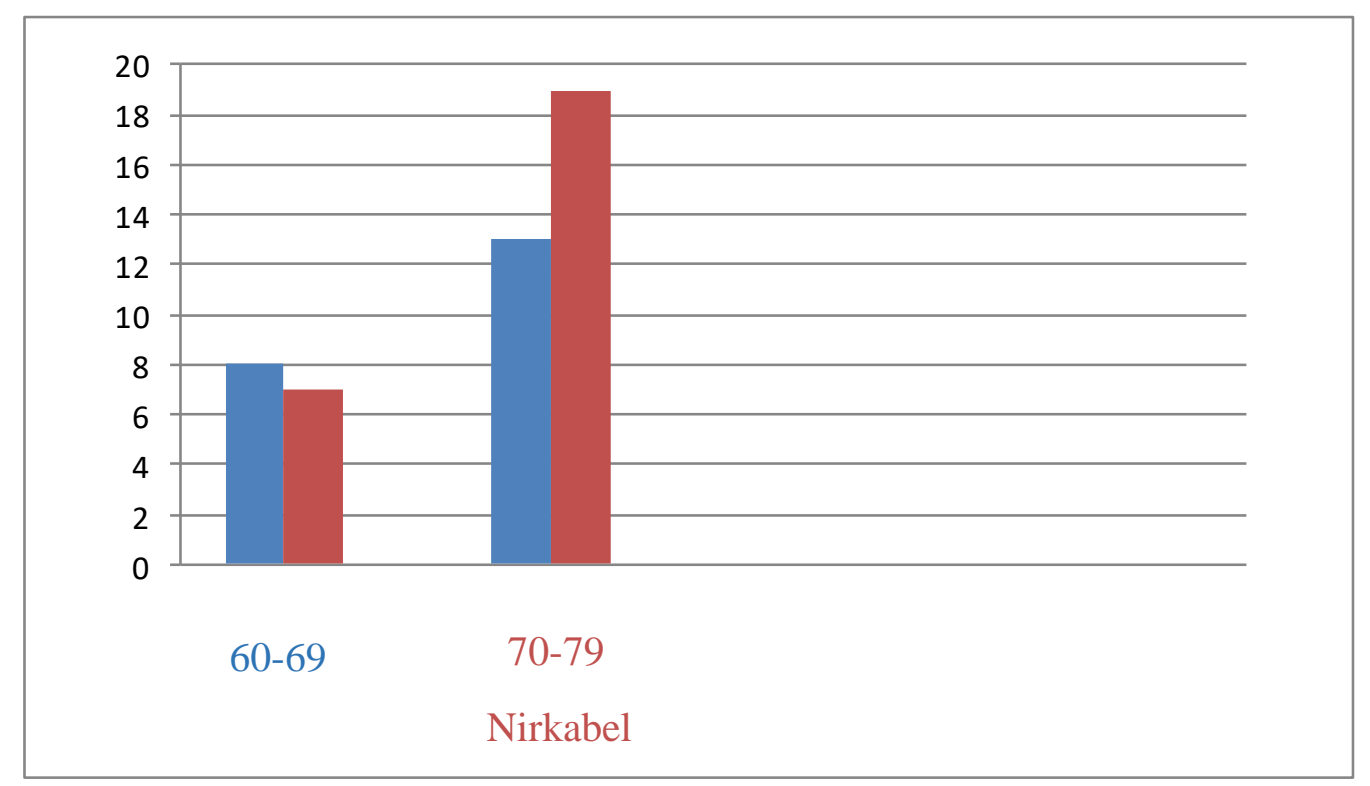

Gambar 1. Hasil Belajar Siswa dalam Siklus 1

Dari Gambar 1 dapat diketahui bahwa dengan menerapkan media pembelajaran interaktif berbasis adobe flash tampak bahwa nilai rata-rata siswa adalah 70,28 dengan nilai terendah 60 dan nilai tertinggi 79. Nilai ketuntasan belajar adalah 7,0 jumlah siswa yang mendapat nilai $\geq 7,0$ sebanyak 21 siswa, yang berarti $60 \%$ dari sejumlah 32 siswa memiliki nilai di atas taraf penguasaan konsep yang diberikan, lebih kecil dari persentase ketuntasan yang dikehendaki yaitu sebesar $95 \%$. Hal ini disebabkan karena siswa masih baru dan asing terhadap metode baru yang diterapkan dalam proses belajar mengajar. Sehingga dapat dikatakan siswa belum banyak memahami tentang konsep pokok bahasan yang dibahas.

Dalam pelaksanaan kegiatan belajar mengajar pada siklus I yang masih terdapat kekurangan-kekurangan, Maka perlu adanya revisi untuk dilakukan pada siklus II antara lain: a) Guru dalam memotivasi siswa hendaknya dapat membuat siswa lebih termotivasi selama proses belajar mengajar berlangsung, b) Guru harus lebih dekat dengan siswa sehingga tidak ada perasaan takut dalam diri siswa, sehingga siswa lebih berkonsentrasi dalam pembelajaran, c) Guru harus lebih bersabar dalam membimbing siswa berdiskusi untuk menemukan hal-hal baru yang berkaitan dengan materi pembelajaran, d) Guru secara intensif memberikan pengertian kepada siswa kondisi dalam berkelompok, kerja sama kelompok, dan keikutsertaan siswa dalam kelompok, e) Guru mengubah jumlah siswa (dari 7 siswa menjadi 5 siswa) dalam satu kelompok, f) Guru membantu kelompok yang belum memahami langkah-langkah pembelajaran interaktif berbasis adobe flash, g) Guru memberikan dorongan dan motivasi kepada siswa untuk lebih aktif mencari sumber belajar, diharapkan agar siswa memperoleh hasil yang diharapkan. 


\section{Paparan Hasil Tindakan Siklus II}

Pertama, Perencanaan di mulai dengan membentuk kelompok diskusi. Siswa yang berjumlah 32 siswa dibagi menjadi 8 kelompok sehingga masing-masing kelompok berjumlah 4 siswa. Materi pelajaran yang diajarkan pada siklus II ini tetap pada pokok bahasan nirkabel Proses pembelajaran pokok bahasan ini menggunakan pembelajaran interaktif berbasis adobe flash. yang diterapkan oleh guru secara langsung dalam pembelajaran di kelas. Kegiatan yang dilakukan oleh peneliti pada tahap perencanaan pada siklus II adalah: a) Peneliti melakukan analisis kurikulum untuk menentukan Standar Kompetensi dan Kompetensi Dasar yang disampaikan kepada siswa dengan menggunakan pembelajaran interaktif berbasis adobe flash, $b$ ) Membuat RPP dengan model pembelajaran interaktif berbasis adobe flash siklus II, c) Membuat lembar observasi siklus II untuk melihat bagaimana kondisi belajar mengajar di kelas ketika latihan dan kerja kelompok dilaksanakan, d) Membuat Lembar Kerja Siswa siklus II, e) Membentuk kelompok (terdiri dari 4 siswi) yang bersifat heterogen baik dari segi kemampuan akademis,dengan menggunakan pembelajaran interaktif berbasis adobe flash pada siklus II, f) Menyusun alat evaluasi pembelajaran berdasarkan perkembangan pada siklus II serta menyiapkan instrumen pendukung pembelajaran lainnya.

Kedua, Pelaksanaan kegiatan belajar mengajar dengan media pembelajaran interaktif berbasis adobe flash. Untuk siklus II dilaksanakan di kelas XI TB 3 SMKN 1 Dlanggu dengan jumlah siswa 32. siswi materi nirkabel . Dalam hal ini Peneliti bertindak sebagai guru. Pengamatan (observasi) dilaksanakan bersamaan dengan pelaksanaan pembelajaran. Pelaksanaan tindakan disesuaikan dengan RPP (Rencana Pelaksanaan Pembelajaran) dan lembar kerja yang telah dibuat dan mengacu pada revisi siklus I, sehingga kekurangankekurangan pada siklus I tidak terulang pada siklus II. Adapun proses belajar mengajar mengacu pada rencana pembelajaran yang telah dipersiapkan dengan menggunakan pembelajaran interaktif berbasis adobe flash, dengan tahapan, presentasi kelas, kerja kelompok, tes individu, dan penghargaan kelompok.

Pelaksanaan tindakan siklus II dapat diuraikan sebagai berikut: a) Guru mengawali pembelajaran dengan mengucapkan salam dan menanyakan jumlah siswa yang hadir, b) Guru melaksanakan apersepsi, c) Guru membagi siswa dalam kelompok diskusi, kemudian memberi tugas yang berkaitan dengan penggunaan media pembelajaran interaktif berbasis adobe flash, d) Guru memberi tugas kepada siswa untuk mempresentasikan di depan kelas hal-hal yang berkaitan nirkabel dengan menggunaan model pembelajaran interaktif berbasis adobe flash waktu untuk presentasi adalah 5 menit untuk masing-masing kelompok, e) Guru menindaklanjuti pembelajaran itu dengan menerangkan materi pelajaran tentang hal-hal yang berkaitan dengan materi nirkabel atas menggunakan model pembelajaran permainan, waktu yang digunakan selama 10 menit, f) Guru bersama-sama siswa mendemonstrasikan penggunaan pembelajaran interaktif materi nirkabel atas selama 10 menit, g) Guru bersamasama siswa melakukan pembelajaran dengan materi nirkabel Guru memberikan tugas secara individu selama 15 menit, h) Guru menutup pelajaran dengan mengucapkan salam.

Selama pembelajaran berlangsung dilakukan observasi untuk mengetahui penerapan Permainandalam meningkatkan hasil belajar siswa dalam proses pembelajaran materi nirkabel. Pada pembelajaran ini siswa yang masuk sebanyak 32. siswa. Bila dilihat dari angka aktivitas guru dan siswa selama kegiatan belajar mengajar, maka secara keseluruhan aktivitas guru dan siswa menunjukkan pembelajaran yang berorientasi interaktif keterampilan proses dalam setting pembelajaran interaktif berbasis adobe flash pada siswa, dimana siswa terlibat aktif dalam pembelajaran.

Pada akhir proses belajar mengajar siklus II siswa diberi tes dengan tujuan untuk mengetahui tingkat keberhasilan siswa dalam proses belajar mengajar yang sudah dilakukan di siklus I, kemudian dikomparasikan dengan hasil pada siklus II. Dalam pembelajaran siklus 
II, konsep-konsep yang teridentifikasi dikembangkan lebih lanjut. Dalam Siklus II ini, berdasarkan catatan peneliti, kerja sama siswa sudah berjalan dengan baik, sehingga masingmasing siswa dapat memecahkan masalah secara individual. Adapun data hasil tes pada siklus II adalah disajikan seperti pada Gambar 2.

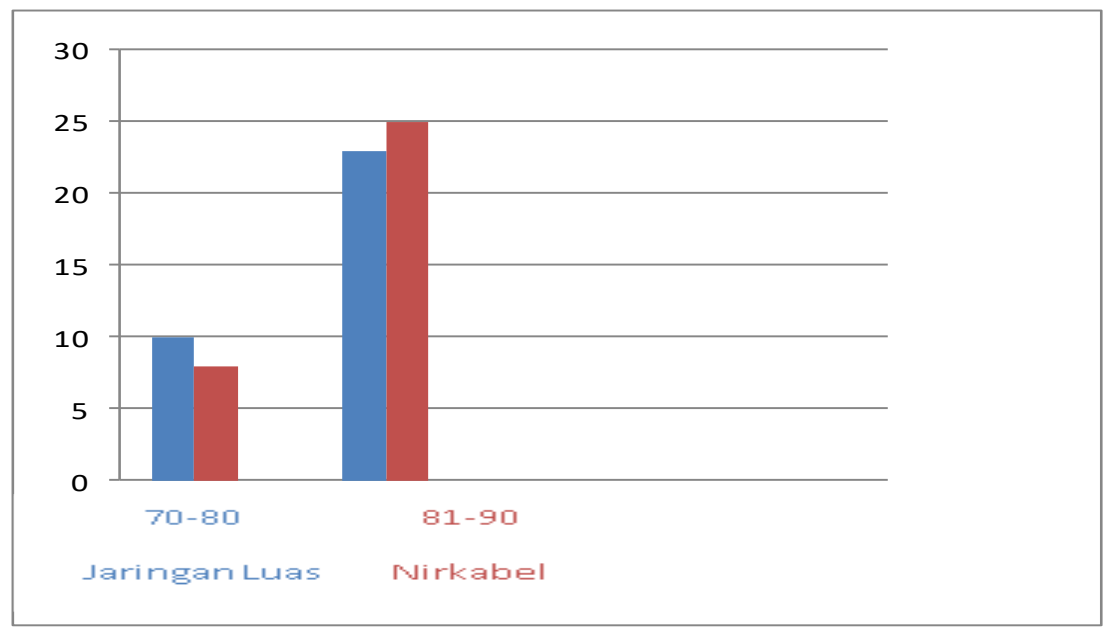

Gambar 2. Nilai Tes Formatif Siswa dalam Siklus 2

Dari Gambar di atas tampak bahwa hasil nilai evaluasi rata-rata siswa secara individual adalah 80,4 dengan nilai terendah 60 dan nilai tertinggi 90. Data diatas menunjukkan bahwa pada siklus II ini, nilai siswa secara individual mengalami peningkatan, yaitu siswa yang tuntas sebanyak 29 siswa dan yang belum tuntas sebanyak 3 siswa, yang berarti 95\% dari sejumlah 32 siswa memiliki nilai di atas taraf penguasaan konsep yang diberikan. Dari siklus 2 ini dapat dikatakan bahwa proses pembelajaran dengan media pembelajaran interaktif berbasis adobe flash dapat meningkatkan hasil belajar siswa.

Dalam pelaksanaan kegiatan belajar mengajar pada siklus II ini masih terdapat kekurangan-kekurangan. Pada tahap ini akan merefleksikan kembali apa yang telah dilaksanakan selama penelitian tindakan kelas dilakukan. Dari data yang diperoleh dapat diuraikan sebagai berikut: a) Selama proses belajar mengajar guru telah melaksanakan pembelajaran dengan cukup baik dengan media pembelajaran interaktif, meskipun ada beberapa bagian yang masih belum sempurna, tetapi presentasi pelaksanaan untuk masingmasing kegiatan sudah cukup baik, b) Berdasarkan data hasil lembar observasi kegiatan kelompok siswa, diadakan perubahan jumlah kelompok pada siklus I sebanyak 8 siswa, dan pada siklus II sebanyak 3 siswa, c) Kekurangan pada siklus I diperbaiki, sehingga pembelajaran menjadi lebih baik pada siklus II, d) Hasil evaluasi siswa mengalami peningkatan dari siklus I ke siklus II dan telah mencapai ketuntasan belajar pada siklus II ini sesuai yang diharapkan yakni peningkatan hasil belajar siswa.

\section{Pembahasan Antar siklus}

Sebelum perlakuan diberikan pada masing-masing kelompok, nilai rerata pretes siswa sebelum diberi perlakuan pembelajaran dengan media interaktif berbasis adobe flash adalah 69,425. Setelah siswa diberi perlakuan pembelajaran dengan interaktif berbasis adobe flash pada siklus I mengalami peningkatan menjadi 70.28, namun hasil ini belum memenuhi target hasil belajar siswa mata pelajaran Penjas orkes yaitu 95\%. Bila dihitung berdasarkan nilai rerata pretes, kelompok siswa yang diberi perlakuan pembelajaran dengan media interaktif berbasis adobe flash. setelah dilaksanaknnya siklus ke II mengalami peningkatan rerata hasil belajar sebesar 80,400-69,425 =10,975. 
Berdasarkan hasil pada sisklus penelitian tersebut di atas, dapat ditunjukkan bahwa adaperbedaan hasil belajar nirkabel antara siswa yang diajar menggunakan metode pembelajaran dengan dibantu media interaktif berbasis adobe flash. Secara objektif harus diakui pengembang bahwa, media pembelajaran interaktif ini terdapat kelebihan/kekuatan dan kekurangan/kelemahan dari produk yang dikembangkan ini. Berikut ini adalah kelebihan/kekuatan dan kekurangan/kelemahan dari media pembelajaran interaktif, diantaranya adalah:

Kelebihan / kekuatan produk pengembangan media pembelajaran interaktif ini antara lain: a) Produk pengembangan ini merupakan media pembelajaran interaktif yang pertama dan sebagai salah satu alternatif sumber belajar baru sebagai strategi pembelajaran di SMK kelas X bagi guru produktif Teknik Komputer dan Jaringan di SMKN 1 Dlanggu Mojokerto, b) Produk pengembangan ini telah mendapatkan validasi oleh ahli isi/materi pembelajaran, ahli media pembelajaran, dan ahli desain pembelajaran, c) Produk pengembangan ini telah diuji cobakan secara perorangan, kelompok kecil, serta uji coba lapangan / kelompok besar, d) Berbagai masukan, saran, maupun kritik dari para ahli serta responden yang didapatkan dari hasil angket/kuesioner telah diakomodir untuk dilakukan Analisa dan revisi terhadap produk pengembangan, e) Produk pengembangan ini dikemas dalam bentuk CD/DVD pembelajaran dan disertai dengan panduan penggunaan di dalamnya agar memudahkan pengguna dalam pengoperasian CD/DVD pembelajaran.

Beberapa kekurangan / kelemahan produk pengembangan media pembelajaran interaktif ini antara lain: a) Dengan terbatasnya waktu penguji cobaan, maka belum semua materi pembelajaran dalam produk pengembangan ini diuji cobakan melalui kegiatan pembelajaran sebenarnya, b) Dengan kerumitan dalam pembuatan produk yang menggunakan peranti lunak adobe flash, sangat menyita waktu dalam pembuatannya sehingga menyebabkan waktu pem-validasian dan penguji cobaan setelah prototype selesai dikembangkan menggunakan ahli dengan syarat minimal, yaitu lulusan pascasarjana (S2) yang idealnya adalah menggunakan para ahli yang lulusan program doktor (S3), c) Para ahli yang ditunjuk sebagai validator untuk memvalidasi produk pengembangan ini masih menggunakan ahli dari kalangan setempat / lokasi penelitian dimana tempat / lokasi penelitian masih merupakan tempat / lokasi unit kerja dari pengembang, sehingga unsur subjektivitas masih kental melekat biarpun dalam hal ini pengembang tetap berusaha se profesional mungkin dengan tanpa ada unsur mempengaruhi dalam pengisian angket/kuesioner yang diberikan pengembang kepada ahli.

Produk pengembangan media pembelajaran interaktif yang dikembangkan ini memiliki identitas sebagai berikut: Bentuk: CD Pembelajaran, Judul: Media Pembelajaran Interaktif Jaringan Dasar, Pengembang: Nizar Agus Diyarrochman, Sasaran: Guru/Pembelajar dan Siswa/Pebelajar, Kapasitas : $156 \mathrm{MB}$.

Hasil penelitian ini juga didukung oleh hasil penelitian Nugraheni (2012) yang menyatakan bahwa ada perbedaan hasil belajar siswa yang yang mendapat perlakuan pembelajaran dengan media pembelajaran interaktif berbasis adobe flash memperoleh ratarata nilai sebesar 80,400, lebih tinggi daripada sebelum siswa diajar dengan model pembelajaran lainnya, yaitu 69,425

Penerapan media pembelajaran interaktif berbasis adobe flash memberikan peningkatatan yang lebih baik pada perolehan hasil belajar nirkabel dari pada penerapan pembelajaran dengan metodel lainya. Dengan kata lain dapat diinter pretasikan bahwa penerapan pembelajaran dengan media pembelajaran interaktif berbasis adobe flash dapat meningkatkan perolehan hasil belajar siswa pada materi nirkabel daripada dengan model pembelajaran yang lainnya. 


\section{Conclusion}

Dari hasil pengembangan yang telah diuji cobakan, maka media pembelajaran interaktif dengan peranti lunak adobe flash pada mata pelajaran jaringan dasar di SMKN 1 Dlanggu-Mojokerto telah berhasil diuji keefektifan, kemenarikan, dan keefisiensiannya dalam pembelajaran. Hal tersebut sudah menunjukkan bahwa media pembelajaran interaktif yang dikembangkan cukup mampu memenuhi kebutuhan guru sebagai alternatif strategi dan mampu meningkatkan strategi guru dalam menyampaikan isi pesan yang terkandung dalam pembelajaran, serta mampu memenuhi kebutuhan akan kejenuhan siswa/pebelajar dalam pembelajaran di dalam kelas X TKJ SMKN 1 Dlanggu-Mojokerto.

\section{References}

Akbar, M., Irhasyuarna, Y., \& Rusmansyah. (2015). Pengembangan Media Pembelajaran Multimedia Interaktif Pada Materi Sistem Koloid. Jurnal Inovasi Pendidikan Sains, 6(1), 65-77.

Anih, E. (2016). Modernisasi Pembelajaran di Perguruan Tinggi Berbasis Teknologi Informasi dan Komunikasi. Jurnal Pendidikan Unsika, 7(1), 185-196. http://journal.unsika.ac.id/index.php/judika

Farida Hasan Rahmaibu, F. A. F. D. P. (2017). Pengembangan Media Pembelajaran Menggunakan Adobe Flash Untuk Meningkatkan Hasil Belajar PKn. Jurnal Kreatif: Jurnal Kependidikan Dasar, 7(1).

Hidayah, S., Wahyuni, S., \& Ani, H. M. (2017). Penggunaan Media Pembelajaran Interaktif Dengan Aplikasi Adobe Flash Cs6 Untuk Meningkatkan Motivasi Belajar Pada Kompetensi Dasar Menganalisis Peran, Fungsi Dan Manfaat Pajak (Studi Kasus Siswa Kelas XI IPS 1 MAN 1 Jember Semester Genap Tahun Ajaran 2016. Jurnal Pendidikan EkonomI: Jurnal Ilmiah Ilmu Pendidikan, Ilmu Ekonomi Dan Ilmu Sosial, 11(1), 117. https://doi.org/10.19184/jpe.v11i1.5012

Nursidik, H., \& Suri, I. R. A. (2018). Media Pembelajaran Interaktif Berbantu Software Lectora inspire. Desimal: Jurnal Matematika, 1(2), 237. https://doi.org/10.24042/djm.v1i2.2583

Oktiani, I. (2017). Kreativitas Guru dalam Meningkatkan Motivasi Belajar Peserta Didik. Jurnal Kependidikan, 5(2), 216-232. https://doi.org/10.24090/jk.v5i2.1939

Sukartiningsih, M. \&. (2018). Pengembangan Media Pembelajaran Interaktif Berbasis Adobe Flash Untuk Pembelajaran Menulis Teks Eksposisi Siswa Kelas Iii Sekolah Dasar. Jurnal Penelitian Pendidikan Guru Sekolah Dasar, 6(5), 255038.

Syahroni, F. (2014). Persepsi Siswa Terhadap Manfaat Pelaksanaan Praktek Kerja Industri Di Smk N 1 Lembah Gumanti. Bahana Manajemen Pendidikan Jurnal Administrasi Pendidikan Volume 2 Nomor 1, Juni 2014 Halaman 275 - 281, 2(1), 275-281.

Syaparuddin, S., \& Elihami, E. (2020). Peningkatan Motivasi Belajar Siswa Melalui Video Rendahnya motivasi belajar siswa kelas Paket C. Jurnal Edukasi Nonformal, 1(1), 187200.

Usfiyana, I. (2019). Pengembangan Media Pembelajaran Berbasis Adobe Flash Cs6 Untuk Mata Pelajaran Teknologi Informasi Dan Komunikasi (TIK) Di Smp Al-Ishlah Semarang. Joined Journal, 2(1), 60-70.

Windiartha, A. (2017). Pengembangan Media Berbasis Adobe Flash Player. Jurnal Olahraga Prestasi, 13(2), 68-88. 